\title{
Pengembangan Model Pembelajaran Problem Mapping Concept Untuk Meningkatkan Keterampilan Proses Sains
}

\author{
Rayendra Wahyu Bachtiar ${ }^{1}$ \\ ${ }^{1}$ Program Studi Pendidikan Fisika, FKIP, Universitas Jember \\ rayendra_fkip@unej.ac.id
}

\begin{abstract}
Abstrak
Indikator pembelajaran bermakna adalah mahasiswa mampu memecahkan masalah dengan cara sendiri. Cara mahasiswa memecahkan masalah sangat dipengaruhi oleh keterampilan proses sains mahasiswa. Salah satu cara mengetahui bagaimana mahasiswa belajar memecahkan masalah adalah dengan melihat bagaimana mahasiswa memetakan masalah, sehingga akan terlihat cara mahasiswa mengkonstruksi pengetahuannya untuk memecahkan masalah. Oleh karena itu, diperlukan strategi pembelajaran yang dapat mendesain dan melihat bagaimana mahasiswa bisa memecahkan masalah. Penelitian ini bertujuan untuk mengembangkan model pembelajaran problem mapping concept (PMC) dan mengukur efektivitas model pembelajaran PMC terhadap keterampilan proses sains mahasiswa. Desain penelitian untuk pengembangan model pembelajaran PMC adalah metode penelitian dan pengembangan Borg and Gall. Validasi isi dan konstruk kelayakan model pembelajaran PMC dilakukan olah ahli. Hasil validasi menunjukkan model pembelajaran PMC layak digunakan dalam pembelajaran. Dampak model pembelajaran PMC terhadap keterampilan proses sains mahasiswa dilihat dengan membandingkan hasil pretes dan postes keterampilan proses sains. Uji- $t$ berpasangan sisi atas digunakan untuk menganalisis pengaruh model belajar terhadap keterampilan proses sains. Hasil analisis data menunjukkan bahwa model pembelajaran PMC secara signifikan dapat meningkatkan keterampilan proses sains mahasiswa.
\end{abstract}

Kata kunci : keterampilan proses sains, problem mapping concept, model pembelajaran

\section{PENDAHULUAN}

Kompetensi keterampilan merupakan salah satu capaian kompetensi lulusan yang harus dimiliki oleh peserta didik pada tingkat pendidikan dasar, menengah dan tinggi. Permendikbud Nomor 104 Tahun 2014 menjelaskan bahwa standar capaian kompetensi keterampilan lulusan pendidikan dasar dan menengah memiliki kriteria skor minimal 2,67 (rentang skor 1-4). Sedangkan, Permendikbud Nomor 73 Tahun 2013 menjelaskan bahwa standar kompetensi keterampilan yang harus dicapai oleh lulusan pendidikan tinggi program sarjana mengacu pada jenjang Kerangka Kualifikasi Nasional Indonesia (KKNI) adalah mahasiswa mampu mengaplikasikan bidang keahlian dan memanfaatkan Iptek dalam penyelesaian masalah. Selain itu, Permendikbud Nomor 64 tahun 2013 dan Nomor 49 Tahun 2014 tentang standar proses pendidikan di satuan pendidikan dasar, menengah, dan tinggi menjelaskan bahwa proses pembelajaran harus dapat mengembangkan kompetensi sikap, pengetahuan, dan keterampilan. Oleh karena itu, pengembangan kompetensi keterampilan peserta didik dalam proses pembelajaran perlu dilakukan selama peserta didik menempuh pendidikan hingga mencapai standar kompetensi keterampilan lulusan.

Kajian pengetahuan natural science (IPA) dalam proses pembelajaran memerlukan kegiatan metode ilmiah (Bayir, dkk, 2014; Hockicko, dkk, 2015; Inan, dkk, 2010). Selain itu, kebermaknaan belajar pengetahuan fisika akan terwujud jika dilakukan dengan beberapa cara metode ilmiah dan disertai penalaran kognitif terhadap data yang diperoleh maupun gejala alam yang teramati (Wilhelm, 2007). Bahkan, Sejumlah studi menunjukkan bahwa desain pembelajaran IPA yang berorientasi pada pengembangan keterampilan siswa dengan cara metode ilmiah dapat berdampak pada peningkatan tujuan pembelajaran aspek kompetensi pengetahuan (Tsai, 2015; Hugerat, dkk, 2014; Wang, 2015). Dengan demikian, pengembangan kompetensi keterampilan metode ilmiah perlu diintegrasikan dalam proses pembelajaran agar capaian kompetensi pembelajaran dapat diperoleh secara holistik. 
Kompetensi siswa tentang keterampilan proses sains berperan penting dalam kesuksesan proses pembelajaran IPA dengan pendekatan metode ilmiah (Rezba, dkk, 2007. Wang, 2015). Bahkan, standar isi pada kurikulum pendidikan tinggi dinyatakan bahwa capaian kompetensi minimal mahasiswa adalah kompetensi pengetahuan prosedural pada dimensi mencipta. Dengan demikian, keterampilan proses sains diperlukan untuk mengkonstruksi pengetahuan prosedural pada dimensi kognitif mencipta (Yakar, 2014). Selain itu, hasil penelitian tentang keberhasilan pembelajaran di perguruan tinggi dipengaruhi oleh keterampilan proses sains mahasiswa (Chabalengula, dkk, 2012; Hirca, 2015). Hal ini disebabkan karena mahasiswa memiliki keterampilan membangun pengetahuan dengan cara metode ilmiah, sehingga kebermaknaan belajar dapat diperoleh (Hirca, 2015; Yakar, 2014).

Sejumlah studi tentang keterampilan proses sains pada pembelajaran pendidikan tinggi telah dikembangkan (Bayir, dkk, 2014; Chabalengula, dkk, 2012; Hirca, 2015; Yakar, 2014). Namun, capaian keterampilan proses sains masih sering diindikasikan dengan keteralaksanaan metode ilmiah. Dengan demikian, keterampilan proses sains hanya dapat mengembangkan dimensi kognitif menerapkan. Padahal, tuntutan capain kompetensi pada kurikulum pendidikan tinggi KKNI adalah standar proses pembelajaran mampu mengembangkan kemampuan mahasiswa pada dimensi kognitif mencipta. Oleh karena itu, diperlukan penelitian yang dapat mengembangkan keterampilan mahasiswa untuk mengkonstruksi pengetahuan dimensi kognitif mencipta.

Penelitian ini bertujuan untuk mengembangkan strategi pembelajaran yang mendesain aktivitas mahasiswa mengkonstruksi pengetahuan yang dimiliki untuk memetakan cara pemecahan masalah. Penelitian ini mendesain agar mahasiswa mampu mampu mengkonstruksi berbagai pengetahuan yang telah dimiliki untuk memetakan masalah. Setelah terpetakan, mahasiswa didorong untuk mampu mengembangkan teknik penyelesaian masalah. Dalam hal ini, pemetaan untuk memecahkan masalah akan melatih pengetahuan prosedural mahasiswa untuk mencapai dimensi kognitif membangun cara pemecahan masalah (Deniz, 2013; Hirca, 2015; Kaya, dkk, 2014). Oleh karena itu, penelitian ini merupakan hasil adaptasi model pembelajaran berbasis masalah, namun titik fokus penelitian pada aktivitas mahasiswa dalam mengkonstruksi pengetahuan dalam pemetaan masalah.

Strategi membelajarkan fisika mahasiswa di kelas dapat dirancang dengan model pembelajaran berbasis masalah (PBM). PBM menyajikan berbagai permasalahan otentik dan bermakna yang berfungsi sebagai landasan investigasi dan penyelidikan bagi siswa (Arends, 2008:41). Beberapa hasil penelitian tentang penerapan PBM menunjukan bahwa proses pembelajaran memberikan kebermaknaan bagi siswa sehingga berdampak hasil pembelajaran yang baik (Atan, dkk, 2005; Subrata, 2007; Keil, dkk, 2009). Berpijak dari teori dan dukungan penelitian maka rancangan pembelajaran fisika di kelas harus dengan pelibatan aktivitas siswa dimana salah satunya dengan penerapan model PBM.

Polya (1957) menyatakan bahwa cara menyelesaiakan masalah dalam problem solving tidak dapat secara langsung dipahami. Oleh karena itu, metode penyelesaian masalah pada penelitian PBM ini dilakukan dengan teknik pemetaan masalah. Esensi teknik pemetaan masalah dirancang untuk membantu mahasiswa dalam mengembangkan ketrampilan menyelesaikan masalah melalui proses berpikir secara individu maupun berkelompok (Silberman, 2009; Slavin, 2008). Keterampilan berpikir dan kemampuan berpikir kritis berkontribusi dalam keberhasilan pemecahan masalah (Meador, 1997:71; Nurlita, 2008). Kemampuan berpikir siswa yang tinggi memberikan kontribusi yang signifikan terhadap keberhasilannya dalam memecahkan masalah secara efektif (Abdullah \& Shariff, 2008; Ozden \& Gultekin, 2008; Setyowati, 2011).

Konsep merupakan dasar untuk berpikir dan berkomunikasi (Arends, 2008: 322). Konsep membuat siswa dapat mengklasifikasikan berbagai objek dan ide sehingga membuat suatu aturan dan prinsip. Konsep menjadi dasar ide-ide yang menuntun pemikiran siswa. Apabila dasar berpikir siswa lemah maka akan mempengaruhi hasil pemikiran siswa. Oleh karena itu, proses pemecahan masalah perlu dilakukan dengan teknik pemetaan masalah, agar mahasiswa bisa lebih memahami bagaimana menganalisis masalah tersebut dari berbagai sudut pandang. 
JPFK, Vol. 1 No. 2, September 2015, hal 90 - 98 http://e-journal.ikippgrimadiun.ac.id/index.php/JPFK

Sistem perundangan pendidikan perguruan tinggi dan tantangan globalisasi menuntut lulusan perguruan tinggi harus memiliki keterampilan untuk menganalisis masalah. Oleh karena itu, diperlukan pengembangan model proses pembelajaran di perguruan tinggi yang dapat mengkonstruksi keterampilan mahasiswa untuk memecahkan masalah. Berpijak dari pentingnya hal tersebut, maka dilakukan penelitian yang berjudul "Pengembangan Model Pembelajaran Problem Mapping Concept Pada Matakuliah Elektronika Dasar Untuk Meningkatkan Keterampilan Proses Sains"

\section{METODE PENELITIAN}

Desain penelitian ini merujuk pada strategi penelitian dan pengembangan Borg and Gall (1983) serta Sugiyono (2010) yang disesuaikan dengan kondisi yang akan dilakukan. Penelitian ini dirancang untuk menghasilkan produk berupa instrumen model pembelajaran problem mapping concept (PMC) yang dapat meningkatkan keterampilan proses sains. Langkah penelitian pengembangan ini yaitu, (1) studi pendahuluan, (2) Desain Produk, (3) Validasi produk, (4) Uji coba instrumen, dan (5) revisi produk akhir.

Tabel 1. Kategori Kelayakan Instrumen

\begin{tabular}{cc}
\hline Rata-rata & Kategori \\
\hline $3,26-4,00$ & Layak \\
\hline $2,51-3,25$ & Cukup layak \\
\hline $1,76-2,50$ & Kurang layak \\
\hline $1,00-1,75$ & Tidak layak \\
\hline
\end{tabular}

Setelah uji validasi, model pembelajaran PMC diterapkan pada pembelajaran mahasiswa yang menempuh mata kuliah Elektronika Dasar. Penerapan model PMC dalam pembelajaran bertujuan untuk mengetahui pengaruh model pembelajaran PMC terhadap keterampilan proses sains mahasiswa. Indikator model pembelajaran PMC berpengaruh terhadap keterampilan proses sains adalah 1) Keterampilan Proses Sain mahasiswa terukur saat proses pembelajaran (in-service); 2) hasil analisis data skor Keterampilan Proses Sains mahasiswa
Uji validasi isi dan konstruk kelayakan instrumen model pembelajaran PMC dilakukan oleh ahli pada bidang desain pembelajaran dan ahli bidang evaluasi pendidikan pembelajaran fisika. Validasi isi dan konstruk digunakan untuk mengetahui tingkat kelayakan produk model pemebalajaran PMC digunakan dalam pembelajaran. Aspek yang dinilai adalah aspek kelayakan isi dan aspek kelayakan penyajian. Aspek kelayakan isi meliputi kesesuaian materi dengan SK dan KD, keakuratan materi, dan materi pendukung pembelajaran. Aspek kelayakan penyajian meliputi teknik penyajian, penyajian pembelajaran, dan kelengkapan penyajian.

Instrumen uji validasi isi dan konstruk menggunakan angket penilaian terhadap produk model pembelajaran PMC dengan skala Likert 1, 2, 3, 4. Data hasil setiap aspek berupa data kuantitatif dan data kualitatif. Data kuantitatif berupa nilai hasil uji kelayakan dan data kualitatif berupa tanggapan, saran, dan kritik dari validator. Indikator kelayakan isi dan konstruk instrumen model pembelajaran PMC dilihat dari skor hasil uji. Kriteria skor kelayakan untuk setiap item pada instrumen disajikan pada Tabel 1.

Tabel 2. Aspek Keterampilan Proses Sains

\begin{tabular}{llc}
\hline \multicolumn{2}{c}{ No } & \multicolumn{1}{c}{ Aspek KPS } \\
\hline \multicolumn{2}{c}{ KPS in-service } \\
\hline KPS Dasar & Nilai Maksimum \\
\hline 1 & Mengobservasi & 4 \\
\hline 2 & Mengukur & 4 \\
\hline
\end{tabular}


JPFK, Vol. 1 No. 2, September 2015, hal 90 - 98

http://e-journal.ikippgrimadiun.ac.id/index.php/JPFK

\begin{tabular}{|c|c|c|}
\hline 3 & Mengklasifikasi & 4 \\
\hline \multicolumn{3}{|c|}{ KPS Terintegrasi } \\
\hline 4 & Menyusun hipotesis & 8 \\
\hline 5 & Menentukan variabel & 8 \\
\hline 6 & Bereksperimen & 8 \\
\hline & Total & 36 \\
\hline \multicolumn{3}{|c|}{ KPS postes } \\
\hline \multicolumn{3}{|c|}{ KPS Dasar } \\
\hline 1 & Mengobservasi & 2 \\
\hline 2 & Mengklasifikasi & 2 \\
\hline 3 & Mengukur & 2 \\
\hline 4 & Menyimpulkan & 2 \\
\hline \multicolumn{3}{|c|}{ KPS Terintegrasi } \\
\hline 5 & Mengidentifikasi Variabel & 2 \\
\hline 6 & Mengkontrol variabel & 2 \\
\hline 7 & Menganalisis Data & 2 \\
\hline 8 & Menginterpretasi Data & 2 \\
\hline 9 & Menyusun hipotesis & 2 \\
\hline 10 & Eksperimen & 2 \\
\hline & Total & 20 \\
\hline
\end{tabular}

Instrumen postes diuji validitas dan reliabilitas terlebih dahulu sebelum digunakan sebagai alat ukur penelitian. Uji validitas meliputi (1) uji isi dan konstruk instrumen dan (2) analisis korelasi tiap butir soal dengan total soal. Aspek uji validasi isi dan konstruk yaitu (1) relevansi indikator soal terhadap aspek keterampilan proses sains, (2) relevansi permasalahan butir soal terhadap indikator, (3) kesesuaian butir soal dengan indikator (4). relevansi permasalahan butir soal terhadap aspek keterampilan proses sains, (5) Imbiguitas butir soal, (6) Tata bahasa permasalahan butir soal, dan (7) probabilitas terpilihnya seluruh pilihan jawaban butir. Uji reliabilitas digunakan untuk mengukur keandalan alat ukur. Uji reliabilitas menggunakan reliabilitas alpha Cronbach. Setelah tes keterampilan proses sains teruji validitas dan reliabilitasnya maka instrumen alat ukur layak dan dapat digunakan untuk uji pretes dan postes keterampilan proses sains mahasiswa.

Pengukuran keterampilan proses sains dilakukan pada mahasiswa yang mengikuti perkuliahan elektronika dasar 1 dengan total peserta 28 mahasiswa. Pengukuran dilakukan saat proses pembelajaran dan setelah pelaksanaan pembelajaran dengan model pembelajaran PMC. Data hasil pengukuran keterampilan proses sains mahasiswa digunakan untuk manganalisis efektivitas penerapan model pembelajaran PMC terhadap keterampilan proses sains.

Uji- $t$ berpasangan sisi atas digunakan untuk menguji apakah terdapat perbedaan yang nyata antara skor in-service dan postes. Hasil pengujian tersebut juga merupakan prediktor untuk menilai apakah model pembelajaran PMC dapat meningkatkan keterampilan proses sains mahasiswa.

\section{Hasil Penelitian dan Pembahasan}

\section{Pengembangan Model PMC}

Kompetensi keterampilan mahasiswa lulusan perguruan tinggi harus memiliki kriteria minimal sesuai pada deskripsi capaian kemampuan kerja KKNI (Permendikbud No 49 Tahun 2014), yaitu mahasiswa mampu mengaplikasikan bidang keahlian dan memanfaatkan Iptek dalam penyelesaian rmasalah (Permendikbud No 73 Tahun 2013). Selain itu, Perguruan Tinggi harus mampu memetakan kebutuhan masyarakat dan tuntutan dunia kerja untuk disesuaikan dengan kedalaman pengetahuan dan keterampilan yang dimiliki mahasiswa. Dengan demikian, keterampilan mahasiswa dalam memanfaatkan pengetahuan yang didapat diperkuliahan perlu dikembangkan sejak proses internalisasi pengetahuan pada pembelajaran di kelas.

Keterampilan mahasiswa yang diperlukan untuk menguasai pengetahuan dan mampu memanfaatkan pengetahuan yang didapat dalam pemecahan masalah sehari-hari adalah keterampilan proses sains (Aydogdu, 2015; Chabalengula dkk, 2012; Deniz, 2013; Hirca, 2015; Kruea-In dkk, 2015; Wilhelm dkk, 2007; Yakar, 2014). Sedangkan keterampilan proses sains mahasiswa dapat dikembangkan ketika proses pembelajaran di kelas. Dengan demikian, dosen harus mampu mendesain pembelajaran yang mampu mengembangkan Keterampilan Proses Sains Mahasiswa. 
JPFK, Vol. 1 No. 2, September 2015, hal 90 - 98 http://e-journal.ikippgrimadiun.ac.id/index.php/JPFK

Keterampilan Proses Sains dapat dilatih ketika mahasiswa diberikan tugas untuk memecahkan masalah (Arend dkk, 2008; Atan dkk, 2005; Aydogdu ,2015; Hirca, 2015; Kruea-In dkk, 2015; Keil dkk, 2009).

Berbagai aktivitas keterampilan proses sains mahasiswa muncul saat proses pemecahan masalah. Namun, saat proses pembelajaran seluruh aktivitas tersebut sangat sulit untuk didokumentasikan dengan baik. Oleh karena itu, diperlukan teknik dokumentasi data keterampilan proses sains mahasiswa dalam memecahkan masalah. Teknik tersebut dapat dilakukan dengan mind mapping untuk memecahkan masalah (Adodo, 2013; Buzan, 2010; Hockickod kk, 2015, Hugerat \& Kortam, 2014; Keles, 2012; Seyihoglu \& Kartal, 2010) dan penelitian ini disebut sebagai Problem Mapping Concept. Berdasarkan hal tersebut, maka tujuan penelitian ini adalah mengembangkan Model model pembelajaran Problem Mapping Concept yang dapat meningkatkan Keterampilan Proses Sains Mahasiswa.
Studi pendahuluan dan pengembangan desain produk menghasilkan produk instrumen model pembelajaran problem mapping concept yang terdiri atas kerangka teoritik, sintaks, bahan ajar, lembar kerja mahasiswa, perangkat penilaian, silabus, dan rencana pelaksanaan pembelajaran. Kemudian, dilanjutkan validasi isi dan konstruk desain model pembelajaran PMC oleh validator yaitu dosen pendidikan fisika universitas jember yang memiliki bidang keahlian evaluasi pendidikan pembelajaran fisika dan desain pembelajaran.

Data hasil setiap aspek berupa data kuantitatif dan data kualitatif. Data kuantitatif berupa nilai hasil uji kelayakan dan data kualitatif berupa tanggapan, saran, dan kritik dari validator. Hasil penilaian terhadap kelayakan model pembelajaran PMC menunjukkan layak digunakan untuk pembelajaran (Tabel 3, Tabel 4 dan Tabel 5). Meskipun demikian, perlu ada perbaikan dari saran dan tanggapan validator.

Tabel 3. Sekor Penilaian Aspek Kelayakan Isi Model Pembelajaran PMC

\begin{tabular}{clcccc}
\hline \multirow{2}{*}{ No } & \multicolumn{1}{c}{ Aspek yang dinilai } & \multicolumn{2}{c}{ Validator } & \multirow{2}{*}{ Rata-rata } & \multirow{2}{*}{ Kategori } \\
\cline { 3 - 4 } & $\begin{array}{l}\text { Kesesuaian Uraian Materi dengan Sk } \\
\text { dan KD }\end{array}$ & 4,00 & 3,75 & 3,88 & \multirow{2}{*}{ Layak } \\
\hline 2 & Keakuratan Materi & 3,75 & 3,50 & 3,63 & Layak \\
\hline 3 & Materi Pendukung Pembelajaran & 3,75 & 4,00 & 3,88 & Layak \\
\hline & Nilai Rata-rata total & 3,83 & 3,75 & 3,80 & Layak \\
\hline
\end{tabular}

Tabel 4. Skor Penilaian Aspek Kelayakan Penyajian Model Pembelajaran PMC

\begin{tabular}{|c|c|c|c|c|c|}
\hline \multirow{2}{*}{ No } & \multirow{2}{*}{ Aspek yang dinilai } & \multicolumn{2}{|c|}{ Validator } & \multirow{2}{*}{ Rata-rata } & \multirow{2}{*}{ Kategori } \\
\hline & & V1 & $\mathrm{V} 2$ & & \\
\hline 1 & Teknik Penyajian & 3,67 & 3,67 & 3,67 & Layak \\
\hline 2 & Penyajian Pembelajaran & 3,53 & 3,80 & 3,67 & Layak \\
\hline \multirow[t]{2}{*}{3} & Kelengkapan Penyajian & 3,83 & 3,83 & 3,83 & Layak \\
\hline & Nilai Rata-rata total & 3,68 & 3,77 & 3,72 & Layak \\
\hline
\end{tabular}

Tabel 5. Ringkasan Skor Uji Kelayakan Model Pembelajaran PMC

\begin{tabular}{|c|c|c|c|c|c|}
\hline \multirow{2}{*}{ No } & \multirow{2}{*}{ Aspek yang dinilai } & \multicolumn{2}{|c|}{ Validator } & \multirow{2}{*}{ Rata-rata } & \multirow{2}{*}{ Kategori } \\
\hline & & V1 & $\mathrm{V} 2$ & & \\
\hline 1 & Kelayakan Isi & 3,83 & 3,75 & 3,80 & Layak \\
\hline \multirow[t]{2}{*}{2} & Kelayakan Penyajian & 3,68 & 3,71 & 3,55 & Layak \\
\hline & Nilai Rata-rata total & 3,68 & 3,77 & 3,72 & Layak \\
\hline
\end{tabular}

2. Hasil Penilaian Keterampilan Proses Sains

Proses pembelajaran dengan desain model PMC mampu mengembangkan Keterampilan Proses Sains. Hal ini dibuktikan pada Tabel 6 yaitu hasil keterampilan proses sains mahasiswa in-service yang diukur menunjukkan skor Keterampilan Proses Sains Dasar 3,51 dan Keterampilan Proses Sains
Terintegrasi 7,44. Selain itu, tingkat penguasaan keterampilan proses sains dasar terintegrasi berturut-turut 0.87 dan 0.85 sehingga dikategorikan baik sekali. Selain itu, secara keseluruhan tingkat penguasaan keterampilan proses mahasiswa saat proses pembelajaran adalah 0.88 dengan kategori baik sekali. 
Tabel 6. Hasil pengukuran Keterampilan Proses Sains (KPS) pada in-service

\begin{tabular}{lllll}
\hline No & KPS & Skor & Penguasaan & Kriteria* \\
\hline 1 & Dasar & 3.51 & 0.87 & Baik Sekali \\
\hline 2 & Terintegrasi & 7.44 & 0.85 & Baik Sekali \\
\hline
\end{tabular}

*Kriteria penguasaan KPS dari Kruea-In dkk (2015)

Alat ukur postes uji keterampilan proses sains dilakukan uji validitas dan reliabilitas terlebih dahulu. Hasil Uji analisis 26 butir soal dihasilkan bahwa 20 butir soal valid dan dapat digunakan sebagai tes Keterampilan Proses Sains. Butir Soal yang tidak valid adalah Soal ke $1,7,10,21,24,25$. Hasil Uji reliabilitas terhadap butir soal valid dihasilkan skor $\mathrm{Kr}-20$ adalah 0,54 sehingga kesimpulannya adalah cukup. Hasil uji validitas isi dan konstruk instrumen postes keterampilan proses sains selengkapnya dapat dilihat pada Tabel 7. Selain itu, data hasil postes Keterampilan Proses Sains terdistribusi normal. Hasil Uji normalitas data tersebut dapat dilihat pada Tabel 8.

Tabel 7. Hasil Uji Validitas Isi Dan Konstruk Instrumen

\begin{tabular}{|c|c|c|}
\hline Aspek 1 & 80 & Sangat kuat \\
\hline Aspek 3 & 65 & kuat \\
\hline Aspek 4 & 70 & kuat \\
\hline Aspek 7 & 65 & Kuat \\
\hline Rata-rata & 68 & Kuat \\
\hline
\end{tabular}

Tabel 8. Hasil Uji Normalitas Data

\begin{tabular}{lcc}
\hline \multirow{2}{*}{ Statistik } & \multicolumn{2}{c}{ Keterampilan Proses Sains } \\
\cline { 2 - 3 } & Postes & Pretes \\
\hline $\mathrm{N}$ & 28 & 28 \\
\hline $\mathrm{L}_{\text {hitung }}$ & 0,113 & 0,152 \\
\hline $\mathrm{L}_{\text {tabel }}$ & 0,161 & 0,161 \\
\hline
\end{tabular}

Total butir soal yang digunakan untuk postes keterampilan proses sains sejumlah 20 butir soal. Instrumen keterampilan proses mengukur 10 indikator, yaitu: (1) mengobservasi, (2) mengklasifikasi, (3) mengukur, (4) menyimpulkan, (5) Mengidentifikasi variabel, (6) menganalisis dan menyusun data, (7) menginterpretasi data, (8) menyusun hipotesis, (9) Mengontrol variabel, (10) melakukan eksperimen.

Hasil uji analisis data antara data penguasaan Keterampilan Proses Sains inservice dengan postes menunjukkan Keterampilan Proses Sains Dasar $p=0,06$. Hal ini menunjukkan tidak ada perbedaan yang signifikan keterampilan proses sains in-service dan postes. Namun, jika dilihat dari skor rereta penguasaan ada perbedaan sebesar 0,01 dengan postes lebih besar daripada in-service. Hasil Keterampilan Proses Sains Terintegrasi menunjukkan $\mathrm{p}=0,01$ sehingga disimpulkan terdapat perbedaan yang signifikan antara postes dengan in-service. Selain itu, skor rerata penguasaan Keterampilan Proses Sains Terintegrasi postes lebih besar daripada inservice yaitu sebesar 0,08 . Secara keseluruhan dapat disimpulkan bahwa Model PMC dapat meningkatkan penguasaan Keterampilan Proses Sains. Hasil Analsis data Keterampilan Proses Sains ditunjukkan pada Tabel 9.

Tabel 9. Hasil analisis data Keterampilan Proses Sains antara in-service dengan postes

\begin{tabular}{lllll}
\hline \multirow{2}{*}{ KPS } & \multicolumn{2}{c}{ Rerata } & \multirow{2}{*}{ Sig(2-tailed) } & \multirow{2}{*}{ Sig } \\
\cline { 2 - 3 } & In-service & postes & & \\
\hline Dasar & 0.87 & 0.89 & 0.06 & 0.05 \\
\hline Terintegrasi & 0.88 & 0.97 & 0.01 & 0.05 \\
\hline
\end{tabular}


Desain pembelajaran dengan model Pembelajaran PMC mampu memunculkan aktivitas observasi, mengklasifikasi, pengukuran, berhipotesis, penentuan variabel, kontrol variabel, analisis data, hingga mengkonstruksi pengetahuan untuk melakukan eksperimen. Aktivitas mahasiswa yang muncul pada desain pembelajaran tersebut merupakan Keterampilan Proses Sains (Rezba dkk, 2007). Hasil ini didukung oleh beberapa penelitian menunjukkan bahwa desain pembelajaran berbasiskan masalah berpengaruh positif terhadap keterampilan proses sains mahasiswa (Chabalengula dkk, 2012; Hirca, 2015; Kaya dkk, 2013; Keil dkk, 2009; Tatar \& Oktay, 2011;).

Aktivitas Keterampilan Proses Sains Dasar terlihat ketika mahasiswa melakukan identifikasi masalah dengan cara mind mapping. Konsep-konsep yang mendukung untuk identifikasi masalah dapat dibuat skema untuk dibentuk garis penghubung konsep (Keles, 2012; Lai dkk, 2001; Meador, 1997). Aktivitas mahasiswa seperti ini dalam penelitian ini disebut sebagai Problem Mapping Concept (PMC). Produk akhir PMC yang dihasilkan oleh mahasiswa membutuhkan proses mengkonstruksi pengetahuan yang dimiliki mahasiswa. Aktivitas menghubungkan konsep dengan cara konstruksi pengetahuan mampu memunculkan Keterampilan Proses Sains Dasar (Aydogdu, 2015; Kruea-In dkk, 2015; Hirca, 2015; Wilhelm dkk, 2007).

Keterampilan Proses Sains Terintegrasi muncul ketika mahasiswa melakukan aktivitas eksperimen. Aktivitas mahasiswa melakukan eksperimen merupakan serangkaian kegiatan perencanaan, pelaksanaan, dan analisis hasil secara ilmiah (Rezba dkk, 2007). Kegiatan ini mampu mengembangkan Keterampilan Proses Sains (Aydogdu, 2015; Kruea-In dkk, 2015; Hirca, 2015). Meskipun demikian, beberapa hasil penelitian menganjurkan bahwa pemerolehan pengetahuan secara metode penyeledikan ilmiah diperlukan proses kognitif mengkaitkan hasil penyelidikan dengan masalah awal (Kaya dkk, 2013; Lai dkk, 2001; Ozden \& Gultekin, 2008; Wang, 2015). Hasil aktivitas mahasiswa melakukan eksperimen dalam penelitian ini tidak hanya menyajikan analisis dan kesimpulan yang menunjukkan ketercapaian tujuan eksperimen, namun mahasiswa diminta untuk memasukkan hasil tersebut kedalam PMC yang telah dibuat mahasiswa pada tahap identifikasi masalah.
Proses integrasi hasil penelitian ke dalam PMC merupakan bentuk pengembangan Keterampilan Proses Sains Terintegrasi (Aydogdu, 2015; Kruea-In dkk, 2015; Rezba dkk, 2007).

\section{KESIMPULAN}

Berdasarkan hasil penelitian dan analisis data dapat disimpulkan pengembangan Model Pembelajaran Problem Mapping Concept (PMC) layak digunakan dalam kegiatan pembelajaran. Selain itu, Model Pembelajaran Problem Mapping Concept dapat meningkatkan keterampilan proses sains mahasiswa.

\section{DAFTAR PUSTAKA}

Abdullah, S. \& Shariff, A. (2008). The Effects of Inquiry-Based Computer Simulation with Cooperative Learning on Scientific Thinking and Conceptual Understanding of Gas Law. Eurasia Journal of Mathematics, Science, \& Technology Education, 4(4): 387-389.

Adodo, S.O. (2013). Effect of Mind-Mapping as a Self-Regulated Learning Strategy on Students' Achievement in Basic Science and Technology. Mediterranean Journal of Social Sciences, 4(6). DOI: 10.5901/mjss.2013 .v4n6p163.

Arends, Richard I. (2008). Learning To Teach Belajar Untuk Mengajar. Yogyakarta: Pustaka Pelajar.

Atan, H., Sulaiman, F. \& Idrus, Rozhan M. (2005). The Effectiveness of Problem-Based Learning in the Web-Based Environment for The Delivery of An Undergraduate Physics Course. International Education Journal, 6(4): 430437.

Aydogdu, B. (2015). The investigation of science process skills of science teachers in terms of some variables. Educational Research and Reviews, 10(5):1990-3839. DOI: 10.5897/ERR2 015.2097.

Bayir, E., Cakici, Y., \& Ertas, O. (2014). Exploring Natural and Social Scientists' Views of Nature of Science. International Journal of Science Education, 36(8): 1286-1312. DOI: 10.1080/ 09500693.2013.860496.

Borg, Walter R., \& Gall, Meredith D. (1983). Educational Research: An Introduction. London: Longman Inc. 
Buzan, T. (2010). Buku Pintar Mind Map. Jakarta: PT. Gramedia Pustaka Utama.

Chabalengula, Vivien Mweene; Mumba, Frackson; Mbewe, Simeon. (2012). How Pre-Service Teachers' Understand and Perform Science Process Skills. EURASIA Journal of Mathematics, Science \& Technology Education, 8(3): 167-175.

Deniz, S. (2013). The Relationship between Emotional Intelligence and Problem Solving Skills in Prospective Teachers. Educational Research and Reviews, 8(24): 2339-2345.

Hirca, N. (2015). Developing a Constructivist Proposal for Primary Teachers to Teach Science Process Skills: "Extended" Simple Science Experiments (ESSE). Asia-Pacific Forum on Science Learning and Teaching, 16(1).

Hockicko, P., Krišták, L., \& Nemec, M. (2015). Development of Students' Conceptual Thinking by Means of Video Analysis and Interactive Simulations at Technical Universities. European Journal of Engineering Education, 40(2): 145-166. DOI: 10.1080/03043797.2014. 941337.

Hugerat, M., \& Kortam, N. (2014). Improving Higher Order Thinking Skills among Freshmen by Teaching Science through Inquiry. EURASIA Journal of Mathematics, Science \& Technology Education, 10(5): 447-454. DOI: 10.12973/ eurasia.2014.1107a.

Inan, H. Z., Trundle, K. C., \& Kantor, R. (2010). Understanding Natural Sciences Education in a Reggio Emilia-Inspired Preschool. Journal of Research in Science Teaching, 47(10): 11861208. DOI: 10.1002/tea.20375.

Kaya, D., Izgiol, D., \& Kesan, C. (2013). The Investigation of Elementary Mathematics Teacher Candidates' Problem Solving Skills According to Various Variables. International Electronic Journal of Elementary Education, 6(2): 295-314.

Keil, C., Haney, J. \& Zoffel, J. (2009). Improvements in Student Achievement and Science Process Skills Using Environmental Health Science Problem-Based Learning Curricula. Electronic Journal of Science Education, 13(1): 1-18.

Keleş, Ö. (2012). Elementary Teachers' Views on Mind Mapping. International Journal of
Education, $\quad 4(1) . \quad$ DOI:

http://dx.doi.org/10.5296/ije.v4i1.1327.

Kruea-In, C., Kruea-In, N., \& Fakcharoenphol, W. (2015). A Study of Thai In-Service and PreService Science Teachers' Understanding of Science Process Skills. Procedia-Social and Behavioral Sciences, 197(2015): 993-997.

Lai, K., Griffin, P., A. Wu, M. \& Dulhunty, M. (2001). Modelling Strategies in Problem Solving. Makalah disajikan pada The 2001 annual Conference of The Autralian Association for Research in Education, Perth, 2-6, Desember 2001

Meador, Karen S. (1997). Creative Thinking and Problem Solving for Young Learners. USA: Greenwood Publishing Group.

Nurlita, F. (2008). Penggunaan Perangkat Pembelajaran Berdasarkan Masalah untuk Meningkatkan Pemahaman Konsep dan Mengembangkan Keterampilan Berpikir Kritis. JIPP, 2008:885-901.

Ozden, M. \& Gultekin, M. (2008). The Effects of Brain-Based Learning on Academic Achievement and Retention of Knowledge in Science Course. Electronic Journal of Science Education, 12(1): 1-17.

Rezba, Richard J, Constance R. Sparague, Jacqueline T. McDonnough, Juanita J. Matkins. (2007). Learning \& Assessing Science Process Skills.USA: Kendal/Hunt Publishing Company.

Polya, G. (1957). How to Solve it, $2^{\text {nd }}$ ed. Princeton University Press. (Online),(http://www. mathgym.com.au/htdocs/polyab.htm, diakses 1 Agustus 2015).

Setyowati, A. (2011). Implementasi Pendekatan Konflik dalam Pembelajaran Fisika untuk Menumbuhkan Kemampuan Berpikir Kritis Siswa SMP Kelas VIII. . Jurnal Pendidikan Fisika Indonesia, 7: 89-96.

Seyihoglu, Aysegul; Kartal, Ayca. (2010). The Views of the Teachers about the Mind Mapping Technique in the Elementary Life Science and Social Studies Lessons Based on the Constructivist Method. Educational Sciences: Theory and Practice, 10(3): 16371656.

Silberman, M. (2009). Active Learning 101 Strategi Pembelajaran Aktif. Yogyakarta: Pustakan Insan Madani. 
JPFK, Vol. 1 No. 2, September 2015, hal 90 - 98 http://e-journal.ikippgrimadiun.ac.id/index.php/JPFK

Slavin, R. E. (2008). Cooperative Learning Teori, Riset, dan Praktik (cetakan ketiga). Bandung: Nusa Dua.

Sugiyono. (2010). Metode Penelitian Kuantitatif Kualitatif dan $R \& D$. Bandung: Alfabeta.

Tatar, E. \& Oktay, M. (2011). The Effectiveness of Problem-Based Learning on Teaching the First Law of Thermodynamics. Research in Science \& Technological Education, 29(3): 315-332.

Tsai, C. (2015). Improving Students' PISA Scientific Competencies through Online Argumentation. International Journal of Science Education, 37(2): 321-339. DOI: 10.1080/09500693.2014. 987712.

Wang, C. (2015). Scaffolding Middle School Students Construction of Scientific Explanations: Comparing a Cognitive versus a Metacognitive Evaluation Approach. International Journal of Science Education, 37(2): 237-271. DOI: 10.1080/09500693.2014. 979378.

Wilhelm, J., Thacker, B. \& Wilhelm, R. (2007\{. Creating Constructivist Physics for Introductory University Classes. Electronic Journal of Science Education, 11(2): 19-37.

Yakar, Z. (2014). Effect of teacher education program on science process skills of preservice science teachers. Educational Research and Reviews, 9(1): 17-23. DOI: 10.5897/ERR2013.1530. 